\title{
Influence of grazing management on intake and composition of cattle diets
}

\author{
DAVID J. HIRSCHFELD, DONALD R. KIRBY, JOEL S. CATON, STEVEN S. SILCOX, \\ AND K.C. OLSON
}

\begin{abstract}
Authors are student, Vermont Law School, Environmental Law Center, South Royalton, Vt. 05068, professor and associate professor, Animal and Range Sciences Department, North Dakota State University, Fargo, N.D. 58105 , graduate student, Animal and Range Sciences Department, New Mexico State University, Las Cruces, N.M. 88003, and graduate student, Department of Animal Science and Industry, Kansas State University, Manhattan, Kan. 66506. Direct reprint requests to Kirby.
\end{abstract}

\begin{abstract}
A study was conducted to evaluate the influences of seasonlong and short duration grazing management on the botanical composition, chemical composition, and organic matter intake of cattle diets in the Northern Great Plains. Four sampling periods; spring, early summer, late summer, and early fall, were conducted during the grazing seasons of 1990 and 1991. Six ruminally cannulated crossbred steers were used to collect diets while 10 ruminally cannulated crossbred heifers were used to establish intake values. In each sampling period, diet collections were obtained from the steers, allowed to graze for 60 to $90 \mathrm{~min}$ in each of the treatments after total rumen evacuation. Intake was estimated using an indigestible marker and twice-daily fecal collections from 5 heifers under each of the 2 treatments. The primary constituent of cattle diets in both seasonlong and short duration treatments was graminoid which was consumed in slightly greater quantity under short duration management. Nutritional content of the diet was improved under short duration management. This is most notable with regard to nitrogen and digestibility, which were higher $(P<0.05)$ in the short duration treatment in $\mathbf{5}$ of the sampling periods. Organic matter intake trended higher for cattle under short duration management with 3 of the analyzed sampling periods showing differences $(P<0.10)$. These results suggest that livestock grazing under a properly implemented rotational grazing system may be presented with an opportunity to consume more of higher quality forage.
\end{abstract}

Key Words: grazing system, Northern Great Plains, range nutrition

Grazing systems have been the focus of much attention in recent years (Holechek et al. 1989), largely because of claims of increased livestock carrying capacity along with a simultaneous improvement in the condition of the rangeland on which a system is implemented (Savory 1978, Walton et al. 1981, Merrill as cited by Gray et al. 1982). Receiving less consideration, though, are the nutritional impacts upon livestock when maintained under such systems. Given the potentially significant advantages to be

Manuscript accepted 18 June 1995. derived from grazing systems (Malechek and Dwyer 1983), it is imperative that assessment of the validity and extent of these benefits continue.

Kothmann et al. (1986) found that cattle diets selected from continuous and rotational grazing in Texas were similar in both botanical and chemical composition. A study by Walker et al. (1989) concurred with this but asserted that rotational grazing might increase the opportunity for selective grazing on Texas rangelands. While Webb (1985) indicated that the latter evaluations are supported by data from North Dakota rangelands as well, Kirby and Webb (1989) concluded that "botanical composition of cow diets was similar between treatments (rotation and season-long) and years". Although the impact of grazing systems on intake is not extensively documented, O'Sullivan (1984) reported differences $(\mathrm{P}<0.001)$ between intake under continuous and rotational grazing in Ireland. Cattle at a low stocking rate and under a rotational grazing treatment consumed $8 \%$ less forage than those under continuous grazing. At a higher stocking rate, animals in the rotation treatment consumed $4 \%$ more forage than those under continuous grazing. In Texas, McKown et al. (1991) also found that organic matter intake was less $(\mathrm{P}<0.001)$ for cattle grazing under a rotation than those under a continuous treatment but did not establish stocking rate as a determinate factor.

Objectives of this study were to examine the nutritional and botanical composition of the diet, and forage intake of cattle under seasonlong (SL) and short duration (SD) grazing management in the Northern Great Plains.

\section{Study Area}

The research was conducted at the Central Grasslands Research Center located in central North Dakota, approximately $14 \mathrm{~km}$ NW of Streeter, N.D. The short duration treatment was located on 129 ha in the N 1/2 of Sec. $25, T 138 N$, R70W while the 64 ha seasonlong treatment was situated in the SE $1 / 4$ of Sec. 25 , T138N, R70W.

The Center is located near the eastern edge of the Missouri Coteau, an area of young morainic hills formed from recent glaciation (Lura 1985). Climate of the study area is characterized by marked seasonal variations in both temperature and precipitation. This region experiences approximately 120 frost-free days 
with a range of monthly temperature means from -13.7 in January to $20.0^{\circ} \mathrm{C}$ in July. Mean annual precipitation of $44.1 \mathrm{~cm}$ is seasonal with over $70 \%$ occurring between May and September.

Forage production on the study site was similar under both grazing treatments as was forage disappearance (Table 1). The close proximity of treatments to one another (fence line border) and relatively uniform topographical and vegetative characteristics explains most of these similarities. Drought conditions experienced in the middle to late 1980's likely influenced species composition of the range. A return to more typical climatic conditions occurred in 1990, leaving the range in a state of recovery during the study period.

Table 1. Forage production and disappearance on range under seasonlong and short duration management at the Central Grasslands Research Center.

\begin{tabular}{lccc}
\hline Management & Year & $\begin{array}{c}\text { Forage } \\
\text { production }\end{array}$ & $\begin{array}{c}\text { Forage } \\
\text { disappearance }\end{array}$ \\
\hline \multirow{3}{*}{ Season- } & 1990 & $(\mathrm{~kg} / \mathrm{ha})$ & $(\%)$ \\
long & 1991 & 2,320 & 55 \\
& Average' & 2,238 & 56 \\
& Range' $^{\prime}$ & 2,306 & 53 \\
Short & $1,370-3,617$ & $41-67$ \\
duration & 1990 & & \\
& 1991 & 2,513 & 58 \\
& Average' $^{1}$ & 2,279 & 60 \\
& Range $^{1}$ & 2,213 & 57 \\
& & $1,196-3,449$ & $41-75$ \\
\hline
\end{tabular}

1982-1991.

The study site was located in the Wheatgrass-Needlegrass vegetation of the Northern Great Plains (Barker and Whitman 1989). Lura et al. (1988) identified 9 range plant communities and one shrub-dominated community on the center. Most prevalent on the study area are the blue grama-needle and thread-sedge (Bouteloua gracilis (H.B.K.) Lag.ex Griffiths-Stipa comata Trin. + Rupr.-Carex heliophila Mack.) and western snowberryKentucky bluegrass (Symphoricarpos occidentalis Hook.-Poa pratensis L.) communities.

\section{Materials and Methods}

The study involved 4 sampling periods in 2 concurrent treatments, short duration and seasonlong, in each of 2 successive years for a total of 8 sampling periods. Sampling periods were arranged within 4 conceptual herbage growth phases during the grazing season: Period 1-late May to early June (spring), Period 2-early July (early summer), Period 3-mid August (late summer), and Period 4-late September to early October (fall) in both 1990 and 1991. This was done in an effort to document differences between the 2 treatments as plant community dynamics varied throughout the season. Each of the sampling periods was approximately 12 days in length.

The short duration treatment consisted of 8 , equally divided paddocks (16.25 ha) radiating northward from a centralized water source. Movement of the herd through these paddocks was every 3 to 7 days, depending upon the rate of herbaceous growth. In spring and early summer when the rate of herbaceous growth was rapid, rotations were shorter. In late summer and fall when growth was slower, rotations were longer. The seasonlong treatment was a single pasture ( $65 \mathrm{ha}$ ) with 2 water sources. There was no herd movement in this treatment. Long-term stocking rates for the seasonlong and short duration treatments were 1.85 and $2.30 \mathrm{AUM} / \mathrm{ha}$, respectively, or approximately $40 \%$ greater for the short duration treatment.

Six, ruminally cannulated, crossbred steers were used for diet collections on each of the 2 treatments. These steers were maintained on a separate seasonlong grazed pasture adjacent to both treatments. Five, ruminally cannulated, crossbred heifers were assigned to graze under each of the treatments (SL and SD). Cannulation techniques were similar to those used by Streeter et al. (1990). Procedures provided for humane treatment of animals and were locally approved. Post operative care consisted of both topical and intramuscular administration of antibiotics similar to those outlined by Caton et al. (1987). Animals, 2 years of age in 1990, remained under the same treatment for both 1990 and 1991. All experimental livestock were maintained with "station herds" under cow-calf management and were subject to such conditions with one major exception. Heifers were implanted with pellets containing $6 \mathrm{mg}$ norgestomet ${ }^{\mathrm{a}}$ every 10 days of the 60 day breeding season to prevent estrus.

Sampling periods began with a single collection of diet samples by the 6 steers. Steers were maintained on a separate pasture until the morning of diet collection. At 0600 hours, they were restrained and subjected to total ruminal evacuation. Ingesta was physically removed from each animal and the rumen was then triple rinsed with water to assure complete removal of contents. Steers were then allowed to graze one of the treatments for 60 to $90 \mathrm{~min}$. Ruminal masticate samples were collected, mixed, subsampled, labeled, and immediately placed on ice. Samples were then frozen at $-20^{\circ} \mathrm{C}$ for later analysis. The same procedure was maintained on the following day for the remaining grazing treatment.

Six days prior to the first fecal collection, heifers in each of the 2 treatments were dosed with a controlled chromic oxide release intra-ruminal device ${ }^{\mathrm{b}}$. Chromic oxide $\left(\mathrm{Cr}_{2} \mathrm{O}_{3}\right)$ was used as an indigestible marker to estimate fecal output (Ellis et al. 1981, Ellis and Rodden 1987, Parker 1990, Adams et al. 1991). In an effort to prevent regurgitation of the device, a $1 \mathrm{~m}$ length of nylon string was attached to the bolus and anchored at the cannula (Harrison et al. 1981). Fecal collections began on day 3 of the sampling period and continued for 8 days. The one exception was in the 3rd period of 1991 when fecal collections began on day 1 and continued through day 8 . Collections were made twice daily at 0600 and 1800 hours for 7 days and at 0600 hours on the 8th day of fecal collections for a total of 15 collections. Upon collection, fresh fecal samples were labeled, dried in a forced air oven at $50^{\circ} \mathrm{C}$, and ground in a Wiley mill to pass a $2-\mathrm{mm}$ screen. Fecal samples were then subsampled and composited by heifer within period on an equal weight basis.

Frozen diet samples were freeze-dried, ground in a Wiley mill to pass a $1-\mathrm{mm}$ screen, and analyzed for botanical and nutrient composition. Approximately $5 \mathrm{~g}$ of each diet sample were shipped to the AAFAB Composition Analysis Laboratory, 1318 Duff Drive, Fort Collins, Colo. 80524, for assessment of dietary

\footnotetext{
${ }^{C}$ Ceva Laboratories, Inc. Overland Park, Kan.

${ }^{b}$ Captec Pty. Ltd., Laverton, Victoria, Australia.
} 
botanical composition. The technique used by the laboratory closely followed that of Sparks and Malechek (1968). Dry matter (DM), ash, acid detergent fiber (ADF), and nitrogen (N) values were determined following standardized procedures (AOAC 1990). Neutral detergent fiber (NDF) analysis was conducted as outlined by Robertson and Van Soest (1981) and acid detergent lignin (ADL) were determined for each of the diets following the procedures of Goering and Van Soest (1970). Crude protein (CP) in diets was determined using the Kjeltec Auto System II (Tecator Co., Hoganas, Sweden), soluble nitrogen (SN) by the $0.15 \mathrm{M} \mathrm{NaCl}$ procedure of Waldo and Goering (1979), acid detergent insoluble nitrogen (ADIN) estimated as the $\mathrm{N}$ component of $\mathrm{ADF}$ residue, and available nitrogen (AN) was by the difference between total nitrogen and ADIN. In vitro organic matter digestibility (IVOMD) was estimated by a modified procedure of Tilley and Terry (1963) where samples were centrifuged and the supernatant fluid was discarded prior to addition of pepsin.

Fecal samples were prepared for chromium analysis by the procedure outlined by Williams et al. (1962). Chromium concentration in the feces was then analyzed by atomic absorption spectrophotometry (Model 461 Perkin Elmer, Norwalk, Conn.) using air-plus acetylene flame. Total fecal output (FO) was calculated by dividing the daily release rate ( $\mathrm{g}$ ) provided by manufacturer by the chromium concentration in the feces ( $/ \mathrm{g} / \mathrm{DM})$. Organic matter intake (OMI) was then estimated by dividing FO (OM basis) by 1-IVOMD and expressed as $\mathrm{kg} /$ day and $\mathrm{g} / \mathrm{kg}$ of body weight (BW). Intake expressed as $\mathrm{g} / \mathrm{kg}$ of BW was calculated in 1990 based on cattle weights as estimated by initial heifer weights and herd average daily gain of the "station herd". In 1991, intake was estimated by using heifer initial and final weights.

For each of the nutritional characteristics of the diet $(O M$, IVOMD, NDF, ADF, ADL, CP, ADIN, N, SN, and AN) and for the graminoid, forb, and shrub components of the botanical composition, a paired t-test was used to determine differences between treatment means (Sokal and Rohlf 1981). This test was applied because the animals used to collect the data were the same for each treatment and individual animals were used as experimental units and thus were not independent. For the analysis of treatment effects on intake, an unpaired t-test was applied. An F-test of the variances allowed for an assessment of their homogeneity or heterogeneity. If the variances of the treatment means were found to be significantly different $(P<0.05)$, then an unpaired t-test for unequal variances was used, otherwise, a test for equal variances was applied (SAS 1988). Differences were ascribed to treatment means which differed at the $\mathrm{P}<0.05$ and at the $P<0.10$ levels. Each of these tests was performed by the GLM procedure of SAS. Diets for period 1 of 1990 were not statistically analyzed because only 1 diet sample for the short duration treatment was available.

\section{Results}

\section{Botanical Composition}

Graminoids dominated the botanical composition of cattle diets ranging from $72.4 \%$ under the seasonlong treatment of period 3 , 1991 to $98.7 \%$ of the diet under the short duration treatment of period 4, 1990 (Table 2). Some of the principal species comprising the graminoid component of the diet included western wheatgrass (Agropyron smithii Rydb.), Kentucky bluegrass, needleand-thread, big bluestem (Andropogon gerardii Vitman), little bluestem (Schizachyrium scoparium (Michx.) Nash), threadleaf sedge (Carex filifolia Nutt.), blue grama and prairie junegrass (Koeleria pyramidata (Lam.) Beauv.) (Table 2). Differences $(\mathrm{P}<0.05)$ between treatment means were observed in period 4 of 1990 and periods 1 and 3 of 1991 . In each of these instances, graminoid selection was greater by cattle under short duration management.

Forbs in diets ranged from $1.1 \%$ in the seasonlong treatment of period 4, 1990 to $27.0 \%$ in the seasonlong treatment of period 3, 1991. Primary constituents of the forb component included fringed sagebrush (Artemisia frigida Willd.) and members of the Asteraceae family (Table 2). Differences in forb consumption were noted in period 4,1990, and in period 1 and 3 of 1991. In these instances, forb consumption was greater $(\mathrm{P}<0.05)$ by those animals under seasonlong management.

Shrubs were not prevalent in cattle diets at any time during this study. Shrub selection ranged from 0\% for most of 1990 to $5.3 \%$ of the diet in the seasonlong treatment of period 4, 1991. The only species comprising the shrub component of the diet was western snowberry. In period 4 of 1990, shrubs were selected in greater amount $(\mathrm{P}<0.10)$ in the seasonlong compared with the short duration treatment.

\section{Chemical Composition}

Neutral detergent fiber in cattle diets ranged from $69.4 \%$ in period 4 of 1991 on the short duration treatment to a high of $84.8 \%$ in period 2 of the same year on the short duration treatment (Table 3). Differences $(\mathrm{P}<0.05)$ were noted between treatments in period 4 of both 1990 and 1991 as well as period 1 and 3 of 1991. Where differences $(\mathrm{P}<0.05)$ were observed, NDF was higher under seasonlong management.

Acid detergent fiber in cattle diets ranged from $42.2 \%$ for the short duration treatment in period 1,1991 to $52.2 \%$ for the seasonlong treatment in period 4, 1990 (Table 3). Dietary ADF was different $(P<0.05)$ between the seasonlong and short duration treatments for period 4 of 1990 and 1991 and periods 2 and 3, 1991.

Acid detergent lignin content of grazed diets generally increased numerically each season as forage matured (Table 3 ). Treatment means were different $(P<0.05)$ in periods 4 and 2 of years 1990 and 1991, respectively. In both periods, the ADL fraction in the diet was higher under seasonlong management. Treatment means for period 3, 1991 also differed $(\mathrm{P}<0.10)$ with short duration treatment diets having a larger percentage ADL. Although not different, all remaining periods had numerically lower dietary lignin for cattle grazing the short duration treatment.

Nitrogen and $\mathrm{N}$ fractions of the cattle diets reflected expected trends, generally declining with advance of season (Table 3 ). Between the treatments, there were differences $(\mathrm{P}<0.05)$ noted in most of the periods (Table 3). Except for period 2, 1990, in each of the 6 periods where total $\mathrm{N}$ differed between treatments there was more $(\mathrm{P}<0.05) \mathrm{N}$ in the diets of cattle grazing under short duration than seasonlong management. Nitrogen values ranged from $1.58 \%$ in the seasonlong treatment of period 3, 1991 to $2.96 \%$ in the short duration treatment of period 1,1991 .

An examination of the $\mathrm{N}$ fractions in the diets of cattle grazing under the 2 treatments revealed similar trends as with $\mathrm{N}$. Available $N$ differed $(\mathrm{P}<0.05)$ between treatments with a greater percent in short duration treatment diets compared with the seasonlong treatment in all but 1 of the 6 periods in which differ- 
Table 2. Botanical composition of seasonal cattle diets $(n=6)$ selected under seasonlong (SL) and short duration (SD) grazing management in the Northern Great Plains.

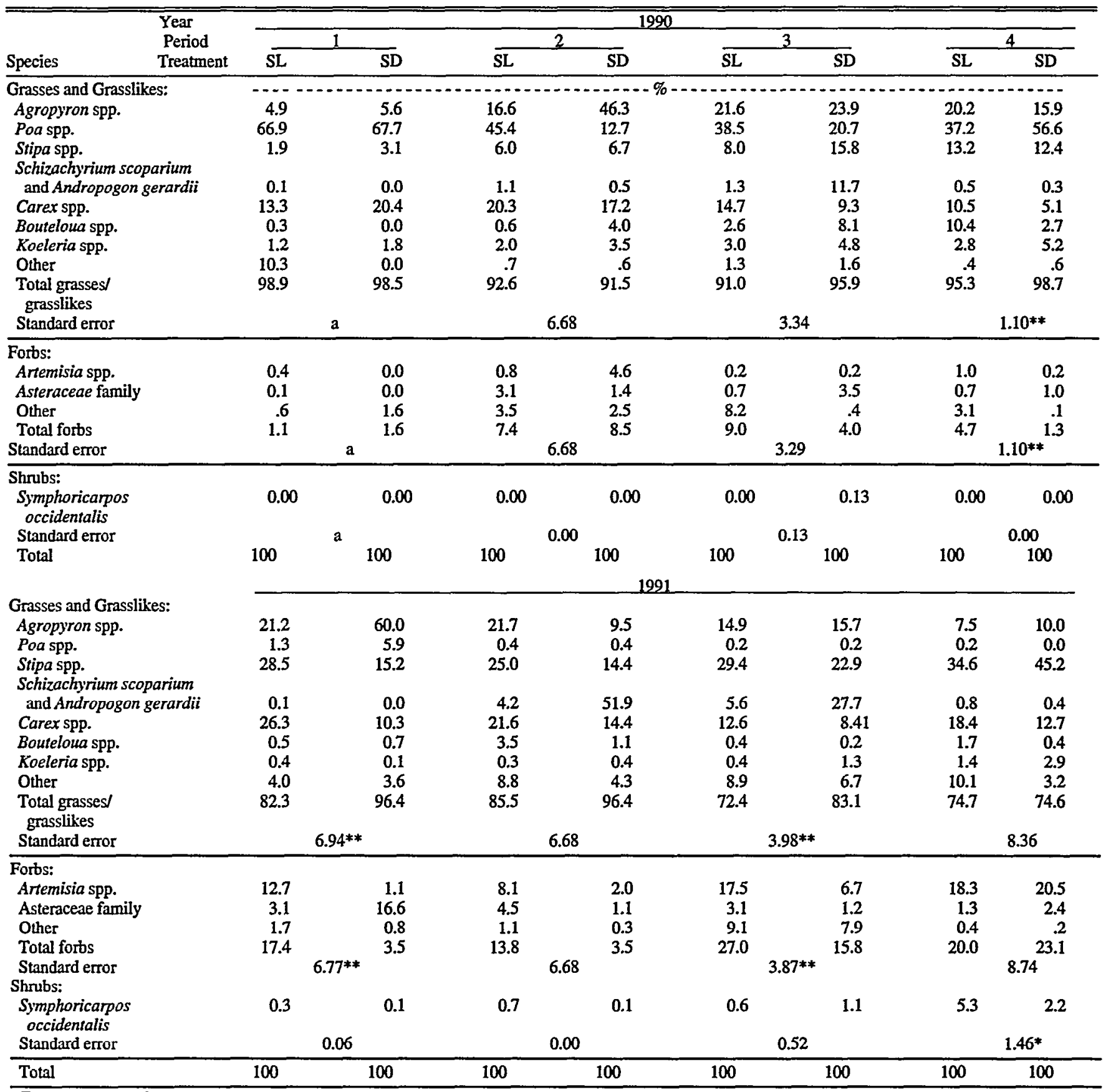

a Treatments not tested.

*,** Treatment means differ at the $P<0.10$ and $P<0.05$ probability level, respectively.

ences were observed. Available $\mathrm{N}$ ranged from $1.41 \%$ in the seasonlong treatment of period 3,1991 to $2.84 \%$ in the short duration treatment of period 1, 1991.

Soluble $N$ of the grazed forage ranged from $0.24 \%$ to $0.83 \%$ for the seasonlong treatments of periods 2 and 3,1990, respectively. Treatment means were found to differ $(P<0.05)$ in periods 2 and 3 of 1990 and periods 1 and 4 of 1991. Treatment means of period 2, 1991 also differed $(P<0.10)$. Except for period 2 of 1990, all periods exhibited higher SN values for the short duration treatment compared to the seasonlong treatment.

Acid detergent insoluble $\mathrm{N}$ of diets varied from $0.11 \%$ in the short duration treatment of period 1,1991 to $0.28 \%$ in the seasonlong treatment, period 4, 1991. In the third period of 1991, short duration diets were higher $(\mathrm{P}<0.05)$ in ADIN than was seasonlong diets, while in the fourth period of the same year, seasonlong diets were higher $(\mathrm{P}<0.05)$ than short duration diets.

In vitro organic matter digestibility of diets ranged from $49.7 \%$ in the seasonlong treatment, period 4 of 1991 to $78.4 \%$ in the short duration treatment, period 1 of the same year (Table 3 ). Periods 2, 3, and 4 of 1990 and periods 3 and 4 of 1991 had differing $(P<0.05)$ treatment means. Period 2 of 1991 was found to have different treatment means at the $\mathrm{P}<0.10$ level. For all peri- 
Table 3. Chemical composition, expressed as percent of organic matter, of cattle diets grazing under seasonlong (SL) and short duration (SD) management in the Northern Great Plains.

\begin{tabular}{|c|c|c|c|c|c|c|c|c|c|c|}
\hline \multirow{2}{*}{$\begin{array}{l}\text { Dietary } \\
\text { component }\end{array}$} & \multirow{2}{*}{$\frac{\text { Year }}{\text { Treatment }}$} & \multicolumn{5}{|c|}{1990} & \multicolumn{4}{|c|}{1991} \\
\hline & & Period & 1 & 2 & 3 & 4 & 1 & 2 & 3 & 4 \\
\hline $\begin{array}{l}\text { Organic } \\
\text { Matter }\end{array}$ & $\begin{array}{c}\text { SL } \\
\text { SD } \\
\text { Std. error }\end{array}$ & & $\begin{array}{l}90.3 \\
88.8 \\
-\end{array}$ & $\begin{array}{l}88.5 \\
88.2 \\
1.01\end{array}$ & $\begin{array}{l}86.2 \\
87.3 \\
0.62\end{array}$ & $\begin{array}{c}86.5 \\
84.5 \\
0.11\end{array}$ & $\begin{array}{l}89.0 \\
89.6 \\
0.36\end{array}$ & $\begin{array}{c}86.3^{* *} \\
88.6^{* *} \\
0.43\end{array}$ & $\begin{array}{c}* 89.2 \\
89.0 \\
0.22\end{array}$ & $\begin{array}{l}87.3 \\
90.3 \\
1.53\end{array}$ \\
\hline NDF & $\begin{array}{c}\text { SL } \\
\text { SD } \\
\text { Std. error }\end{array}$ & & $\begin{array}{l}78.4 \\
70.7 \\
-\end{array}$ & $\begin{array}{c}73.4 \\
72.6 \\
0.69\end{array}$ & $\begin{array}{c}82.1 \\
74.2 \\
4.45\end{array}$ & $\begin{array}{c}81.2^{* *} \\
75.3^{* *} \\
1.75\end{array}$ & $\begin{array}{c}77.5^{* *} \\
73.3^{* *} \\
1.45\end{array}$ & $\begin{array}{l}84.2 \\
84.8 \\
1.09\end{array}$ & $\begin{array}{c}75.4^{* *} \\
71.7^{* *} \\
0.89\end{array}$ & $\begin{array}{c}77.3^{* *} \\
69.4^{* *} \\
2.67\end{array}$ \\
\hline $\mathrm{ADF}$ & $\begin{array}{c}\text { SL } \\
\text { SD } \\
\text { Std. error }\end{array}$ & & $\begin{array}{l}42.6 \\
41.3 \\
-\end{array}$ & $\begin{array}{c}42.4 \\
42.8 \\
0.80\end{array}$ & $\begin{array}{c}50.4 \\
46.5 \\
2.71\end{array}$ & $\begin{array}{c}52.2^{* *} \\
47.8^{* *} \\
1.18\end{array}$ & $\begin{array}{c}43.9 \\
42.2 \\
1.38\end{array}$ & $\begin{array}{c}47.3^{* *} \\
46.1^{* *} \\
0.41\end{array}$ & $\begin{array}{c}48.7^{* *} \\
46.3^{* *} \\
0.56\end{array}$ & $\begin{array}{c}49.2^{* * *} \\
45.2^{* *} \\
0.99\end{array}$ \\
\hline$A D L$ & $\begin{array}{c}\text { SL } \\
\text { SD } \\
\text { Std. error }\end{array}$ & & $\begin{array}{l}3.3 \\
4.1 \\
-\end{array}$ & $\begin{array}{l}3.9 \\
3.5 \\
0.49\end{array}$ & $\begin{array}{l}5.0 \\
4.2 \\
0.49\end{array}$ & $\begin{array}{l}6.4^{* *} \\
5.0^{* *} \\
0.42\end{array}$ & $\begin{array}{l}3.9 \\
3.6 \\
0.28\end{array}$ & $\begin{array}{l}6.4^{* *} \\
4.9^{* *} \\
0.39\end{array}$ & $\begin{array}{l}5.5^{*} \\
5.7^{*} \\
0.11\end{array}$ & $\begin{array}{l}7.5 \\
6.7 \\
1.24\end{array}$ \\
\hline $\begin{array}{l}\text { Total } \\
\text { nitrogen }\end{array}$ & $\begin{array}{c}\text { SL } \\
\text { SD } \\
\text { Std. error }\end{array}$ & & $\begin{array}{l}2.2 \\
1.8 \\
-\end{array}$ & $\begin{array}{l}2.6^{* *} \\
2.3^{* *} \\
0.11\end{array}$ & $\begin{array}{l}1.8 \\
1.7 \\
0.12\end{array}$ & $\begin{array}{l}1.7^{* *} \\
2.2^{* *} \\
0.06\end{array}$ & $\begin{array}{l}2.3 * * \\
3.0^{* *} \\
0.06\end{array}$ & $\begin{array}{l}2.1 * * \\
2.4^{* *} \\
0.05\end{array}$ & $\begin{array}{l}1.6^{* *} \\
2.0^{* *} \\
0.10\end{array}$ & $\begin{array}{l}1.8^{* *} \\
2.3^{* *} \\
0.13\end{array}$ \\
\hline $\begin{array}{l}\text { Available } \\
\text { nitrogen }\end{array}$ & $\begin{array}{c}\text { SL } \\
\text { SD } \\
\text { Std. error }\end{array}$ & & $\begin{array}{l}2.1 \\
1.6 \\
-\end{array}$ & $\begin{array}{l}2.4^{* *} \\
2.1^{* *} \\
0.11\end{array}$ & $\begin{array}{l}1.6 \\
1.6 \\
0.12\end{array}$ & $\begin{array}{l}1.5^{* *} \\
2.0^{* *} \\
0.05\end{array}$ & $\begin{array}{l}2.2^{* *} \\
2.8^{* *} \\
0.07\end{array}$ & $\begin{array}{l}1.8^{* *} \\
2.1^{* *} \\
0.04\end{array}$ & $\begin{array}{l}1.4^{* *} \\
1.7^{* *} \\
0.10\end{array}$ & $\begin{array}{l}1.5^{* *} \\
2.1^{* *} \\
0.12\end{array}$ \\
\hline $\begin{array}{l}\text { Soluble } \\
\text { nitrogen }\end{array}$ & $\begin{array}{c}\text { SL } \\
\text { SD } \\
\text { Std. error }\end{array}$ & & $\begin{array}{l}0.4 \\
0.3 \\
-\end{array}$ & $\begin{array}{l}0.8^{\neq \neq} \\
0.4^{\neq \neq} \\
0.06\end{array}$ & $\begin{array}{l}0.2^{* *} \\
0.4^{* *} \\
0.05\end{array}$ & $\begin{array}{l}0.4 \\
0.5 \\
0.06\end{array}$ & $\begin{array}{l}0.4^{* *} \\
0.6^{* *} \\
0.07\end{array}$ & $\begin{array}{l}0.4^{*} \\
0.4^{*} \\
0.04\end{array}$ & $\begin{array}{l}0.3 \\
0.4 \\
0.05\end{array}$ & $\begin{array}{l}0.5^{* *} \\
0.8^{* *} \\
0.07\end{array}$ \\
\hline ADN & $\begin{array}{c}\text { SL } \\
\text { SD } \\
\text { Std. error }\end{array}$ & & $\begin{array}{l}0.1 \\
0.1 \\
-\end{array}$ & $\begin{array}{l}0.1 \\
0.2 \\
0.02\end{array}$ & $\begin{array}{l}0.2 \\
0.2 \\
0.01\end{array}$ & $\begin{array}{l}0.2 \\
0.2 \\
0.03\end{array}$ & $\begin{array}{l}0.1 \\
0.1 \\
0.02\end{array}$ & $\begin{array}{l}0.3 \\
0.2 \\
0.03\end{array}$ & $\begin{array}{l}0.2 \\
0.2 \\
0.00\end{array}$ & $\begin{array}{l}0.3^{* *} \\
0.2^{* *} \\
0.01\end{array}$ \\
\hline IVOMD & $\begin{array}{c}\text { SL } \\
\text { SD } \\
\text { Std. error }\end{array}$ & & $\begin{array}{l}67.0 \\
69.5 \\
-\end{array}$ & $\begin{array}{c}70.1^{* *} \\
74.1^{* *} \\
0.37\end{array}$ & $\begin{array}{c}54.2^{* *} \\
60.7^{* *} \\
1.19\end{array}$ & $\begin{array}{c}55.6^{* *} \\
60.8^{* *} \\
1.03\end{array}$ & $\begin{array}{c}77.2 \\
78.4 \\
0.93\end{array}$ & $\begin{array}{r}62.8^{*} \\
69.4^{*} \\
0.32\end{array}$ & $\begin{array}{c}59.2^{* *} \\
63.4^{* *} \\
0.66\end{array}$ & $\begin{array}{c}49.7^{* *} \\
62.5^{* *} \\
1.98\end{array}$ \\
\hline
\end{tabular}

Standard error, $n=6$
$*, * *$ Treatment means diffe $\mathrm{r}^{\mathrm{at}}$ the $\mathrm{P}<0.10$ and $\mathrm{P}<0.05$ probability level, respectively.

ods where differences were recognized, short duration treatment diets were higher in IVOMD than those in the seasonlong treatment.

\section{Intake}

Fecal output in $\mathrm{g} \mathrm{kgb.w.}{ }^{-1}$ day $^{-1}$ ranged from 5.8 under short duration management, period 1,1990 to 10.4 under seasonlong management, period 3, 1991 (Table 4). Differences were noted in treatment means for periods 1,3 , and 4 of $1990(\mathrm{P}<0.05)$ and periods 2 of 1990 and 3 of $1991(\mathrm{P}<0.01)$. When intake was determined from fecal output estimates, differences between treatment means were observed for periods 1 and $2(P<0.10)$ and $4(\mathrm{P}<0.05), 1991$ (Table 4). Converted OMI ( $\mathrm{g} \mathrm{kgb.w^{-1 }}$ ) was 6.09 g kgb.w..$^{-1}$ day $^{-1}$ greater $(P<0.05)$ in the short duration than in the seasonlong treatment.

\section{Discussion}

Dietary botanical composition results generally agree with the studies of Allison and Kothmann (1979), Taylor et al. (1980), Pfister et al. (1984), Holechek et al. (1987), Kirby and Webb (1989), Walker et al. (1989), and Silcox (1991) in that the primary constituent of cattle diets are graminoids. Ralphs et al. (1986) found that cattle diets under short-duration grazing management near Sonora, Texas were not always comprised primarily of grasses. This may be particularly true for more arid environments than that of the present study area and is supported by data from southern New Mexico (Krysl et al. 1987).

Impact of stocking rate on botanical composition of diets as documented by Allison and Kothmann (1979), disagrees with the results of this study. Their research indicated that as stocking rate increased, animals were forced to consume less palatable species of forage. This difference is most likely due to the similar availability and use of forage in the 2 treatments of this study as well as differences in stocking rates between the studies. The effect of grazing treatment on dietary botanical composition observed in this study agree with Kirby and Webb (1989) who found a higher graminoid component and lower forb component for cattle under short duration management in the Northern Great Plains. These results conflict with the studies by Holechek et al. (1987) and Walker et al. (1989) who found no effects and Pfister et al. (1984) who found that forb consumption was higher while grass consumption was lower under a rotation system. Species composition of the range, environmental conditions, stocking rates, and livestock management are highly variable from study to study and may explain some of the discrepancies between studies.

Chemical composition of cattle diets generates an approximation of the quality of the diet. In this study, cattle grazing under short duration management were allowed a higher quality diet than those grazing under seasonlong management. Quality, in terms of nitrogen content and digestibility of the forage in the 
Table 4. Fecal output (FO) and organic matter intake (OMI) of cattle grazing under seasonlong (SL) and short duration (SD) management in the Northern Great Plains.

\begin{tabular}{|c|c|c|c|c|c|c|}
\hline \multirow{2}{*}{$\begin{array}{l}\text { Organic } \\
\text { matter } \\
\text { intake }\end{array}$} & \multirow[b]{2}{*}{ Treatment } & \multirow{2}{*}{$\frac{\text { Year }}{\text { Period }}$} & \multicolumn{4}{|c|}{1990} \\
\hline & & & 1 & 2 & 3 & 4 \\
\hline FO & $\begin{array}{c}\text { SL } \\
\text { SD } \\
\text { Std. error }\end{array}$ & & $\begin{array}{l}7.5^{* *} \\
5.8^{* *} \\
0.59\end{array}$ & $\begin{array}{c}- \text { - g ligb } \\
7.7^{*} \\
6.8^{*} \\
0.34\end{array}$ & $\begin{array}{c}-1 \\
\mathrm{day}^{-1} \\
10.3^{* *} \\
7.6^{* *} \\
0.89\end{array}$ & $\begin{array}{c}10.1^{* *} \\
8.0^{* *} \\
0.63\end{array}$ \\
\hline OMI & $\begin{array}{c}\text { SL } \\
\text { SD } \\
\text { Std. error }\end{array}$ & & $\begin{array}{c}22.7 \\
18.9 \\
1.51\end{array}$ & $\begin{array}{c}25.6 \\
26.0 \\
1.23\end{array}$ & $\begin{array}{c}22.6 \\
19.3 \\
1.54\end{array}$ & $\begin{array}{c}22.8 \\
20.4 \\
1.51\end{array}$ \\
\hline FO & $\begin{array}{c}\text { SL } \\
\text { SD } \\
\text { Std. error }\end{array}$ & & $\begin{array}{l}6.3 \\
7.1 \\
0.40\end{array}$ & \begin{tabular}{l}
\multicolumn{1}{c}{10} \\
7.9 \\
8.0 \\
0.66
\end{tabular} & $\begin{array}{r}10.4^{*} \\
8.9 * \\
0.65\end{array}$ & $\begin{array}{l}9.6 \\
9.5 \\
0.81\end{array}$ \\
\hline OMI & $\begin{array}{c}\text { SL } \\
\text { SD } \\
\text { Std. error }\end{array}$ & & $\begin{array}{r}27.6^{*} \\
32.8^{*} \\
1.74\end{array}$ & $\begin{array}{r}21.3^{*} \\
26.1^{*} \\
1.42\end{array}$ & $\begin{array}{c}25.5 \\
24.2 \\
1.27\end{array}$ & $\begin{array}{c}19.1^{* *} \\
25.2^{* *} \\
1.66\end{array}$ \\
\hline
\end{tabular}

Standard error, $n=6$.

*,** Treatment means within years and periods differ at the $\mathrm{P}<0.10$ and $\mathrm{P}<0.05$ proba-

bility level, respectively.

diet, was enhanced under the short duration treatment especially in the latter portion of the grazing season. This is in general disagreement with Holechek et al. (1987), Kirby and Webb (1989), Walker et al. (1989), and McKown et al. (1991) who found either no differences between seasonlong and short duration management or found that cattle diets under a rotation grazing system to be of poorer quality than that of cattle under seasonlong management. While McKown et al. (1991) attributed most of the diet quality differences between rotational and continuous grazing treatments to differences in stocking rate rather than grazing system, that does not appear to be the case in this study. As with dietary botanical composition, much of the conflict in results in research can be explained by an examination of the differing range conditions, environmental variations, stocking rates and livestock management practices involved in each study. While these may describe much of the discrepancy, the differences in our study may also be explained by observing that stocking rate did not exceed a threshold where intake is depressed and diet quality subsequently declines. Walker et al. (1989) state that their data "support the hypothesis that installing rotational grazing at a high stocking rate does not lower diet quality and would not be expected to be a factor affecting individual animal performance". This study would support this concept and suggest that a rotational grazing system could improve diet quality.

Intake by cattle grazing under seasonlong and short duration management indicate that $\mathrm{OMI}$ is either not effected by grazing treatment or is possibly enhanced by the short duration treatment. This is in general agreement with Walton et al. (1981) who studied cattle intake under continuous and rotational grazing management in Alberta. While both O'Sullivan (1984) and McKown et al. (1991) noted instances where cattle intake was lower under a rotational grazing system, O'Sullivan observed a greater efficiency of digestible OMI per unit weight gain in a rotation system. McKown et al. (1991) stipulate that their results were undoubtedly influenced by the quantity and quality of available herbage and that is true here as well. Intake in this study fell well within the bounds of 1 to $2.8 \%$ of body weight stated by Cordova et al. (1978).

\section{Conclusions}

Results indicate that dietary variations do occur between cattle grazing under seasonlong and short duration grazing management in the Northern Great Plains. For both treatments, years, and in all periods, graminoids were the major constituent in cattle diets. An overall assessment of diet quality based on 9 different analyses presents a picture of improved diet quality for cattle grazing under the short duration treatment as opposed to those under seasonlong management. Organic matter intake increased for cattle under short duration management in 3 of 8 collection periods. These observations lend credence to hypotheses which suggest not only enhanced rangeland condition through proper implementation of a rotational grazing system, but that livestock under such a system may be presented with the opportunity to consume more of higher quality forage. Results from this study were undoubtedly influenced by seasonal growing conditions. However, while these conditions were important to the overall nature of the data, they were insignificant in comparisons between the 2 treatments. Opportunities for fall regrowth through periodic rest in the short duration treatment, probably accounted for many of the differences in diet quality between the 2 treatments.

\section{Literature Cited}

Adams, D.C., R.E. Short, M.M. Borman, and M.D. MacNeil. 1991. Estimation of fecal output with an intra-ruminal continuous release marker device. J. Range Manage. 44:204-207.

Allison, C.D. and M.M. Kothmann. 1979. Effect of level of stocking pressure on forage intake and diet quality of range cattle. Amer. Soc. Anim. Sci., West. Sec. Proc. 30:174-178.

AOAC. 1990. Official Methods of Analysis (14th Ed.). Assoc. of Official Anal. Chem., Washington, DC.

Barker, W.T. and W.C. Whitman. 1989. Vegetation of the Northern Great Plains. Research Report \#111. North Dakota State Univ., Fargo, N.D.

Caton, J.S., L.J. Krysl, A.S. Freeman, J.L. Ruttle, and M.E. Branine. 1987. An updated procedure for cecal cannulation in sheep and cattle. J. Range Manage. 40:375-377.

Cordova, F.J., J.D. Wallace, and R.D. Pieper. 1978. Forage intake by grazing livestock: a review. J. Range Manage. 31:430-438.

Ellis, K.J. and B. Rodden. 1987. Measuring faecal output of grazing ruminants using the captec chromic oxide controlled release capsule. 4th AAAP Anim. Sci. Congr., Hamilton, New Zealand (abstr).

Ellis, KJ., R.H. Laby, and R.G. Burns. 1981. Continuous controlledrelease administration of chromic oxide to sheep. Proc. Nutr. Soc. Aust. 6:145.

Goering, H.K. and P.J. Van Soest. 1970. Forage fiber analysis. Agr. Handb. No. 379, ARS USDA, Washington, D.C.

Gray, J.R., C. Steinger Jr., and J.M. Fowler. 1982. Characteristics of grazing systems. Agr. Exp. Sta. Res. Rep. 467. New Mexico State Univ., Las Cruces, N.M.

Harrison, F.A., R.H. Laby, and J.L. Mangan. 1981. A slow release marker capsule for studies of digestion in the sheep. J. Physiol. 319:1.

Holechek, J.L., T.J. Berry, and M. Vavra. 1987. Grazing system influences on cattle performance on mountain range. J. Range Manage. 40:55-59.

Holechek, J.L., R.D. Pieper, and C.H. Herbel. 1989. Range Management Principles and Practices. Prentice Hall. Englewood Cliffs, N.J.

Kirby, D.R. and H.E. Webb. 1989. Cattle diets on rotation and seasonlong grazing treatments. North Dakota Farm Res. 46:14-17.

Kothmann, M.M., E.A. deMoreaes, R.K. Heitschmidt, and J.W. Walker. 1986. Botanical and chemical composition of cattle diets for yearlong continuous and rotation grazing systems. Texas Agr. Exp. Sta. PR 4416-57:26. 
Krysl, L.J., M.L. Galyean, J.D. Wallace, F.T. McCollum, M.B. Judkins, M.E. Branine, and J.S. Caton. 1987. Cattle nutrition on blue grama rangeland in New Mexico. Agr. Exp. Sta. Bull. 727. Las Cruces, N.M.

Lura, C.L. 1985. Range plant communities of the Central Grasslands Research Station. Ph.D. Diss., North Dakota State Univ., Fargo, N.D.

Lura, C.L., W.T. Barker, and P.E. Nyren. 1988. Range plant communities of the Central Grasslands Research Station in south central North Dakota. Prairie Nat. 20:177-192.

Malechek, J.C. and D.D. Dwyer. 1983. Short duration grazing doubles your livestock? Utah Agr. Exp. Sta., Utah Sci. 44:32-37.

McKown, C.D., J.W. Walker, J.W. Stuth, and R.K. Heitschmidt. 1991. Nutrient intake of cattle on rotational and continuous grazing treatments. J. Range Manage. 44:596-601.

O'Sullivan, M. 1984. Measurement of grazing behavior and herbage intake on two different grazing management systems for beef production. Grassland Beef Production: A Seminar in the CEC Programme of Coordination. M. Nijhoff Publishers. p. 141.

Parker, W.J. 1990. Application of intraruminal chromium controlled release capsules to the measurement of herbage intake of sheep at pasture. Ph.D. Diss., Massey Univ., Palmerston North, New Zealand.

Pfister, J.A., G.B. Donart, R.D. Pieper, J.D. Wallace, and E.E. Parker. 1984. Cattle diets under continuous and four-pasture, one-herd grazing systems in southcentral New Mexico. J. Range Manage. 37:50-54.

Ralphs, M.H., M.M. Kothmann, and L.B. Merrill. 1986. Cattle and sheep diets under short-duration grazing. J. Range Manage. 39:217-223.

Robertson, J.B. and P.J. Van Soest. 1981. The detergent system of analysis and its application to human foods. In: W.P.T. James and O. Theander (Ed.) The Analysis of Dietary Fiber. pp. 138-147. Marcel Dekker, New York, N.Y.
Savory, A. 1978. A holistic approach to ranch management using short duration grazing, p. 555., In: D.H. Hyder (Ed.), Proc. Ist Internat. Nat. Rangcland Congr., Soc. Range Manage., Denver, Colo.

SAS. 1988. SAS User's Guide: Statistics. SAS Institute, Cary, N.C.

Silcox, S.C. 1991. Cattle diets in the northern great plains: seasonal influences on composition, intake and in situ degradability. M.S. Thesis, North Dakota State Univ., Fargo, N.D.

Sokal, R.R. and F.J. Rohlf. 1981. Biometry. Second Edition. W.H. Freeman and Company, New York, N.Y.

Sparks, D.R. and J.C. Malechek. 1968. Estimating percentage dry weight in diets using a microscopic technique. J. Range Manage. 21:264-265.

Streeter, M.N., D.G. Wagner, C.A. Hibberd, and F.N. Owens. 1990. Comparison of corn with four sorghum grain hybrids: site and extent of digestion in steers. J. Anim. Sci. 68:3429-3440.

Taylor, C.A., M.M. Kothmann, L.B. Merrill, and D. Elledge. 1980. Diet selection by cattle under high-intensity low-frequency, short-duration, and Merrill grazing systems. J. Range Manage. 33:428-434.

Tilley, J.M.A. and R.A. Terry. 1963. A two-stage technique for the in vitro digestibility of forage crops. J. Bri. Grassl. Soc. 18:104-111.

Waldo, D.R. and H.K. Goering. 1979. Insolubility of protein by four methods. J. Anim. Sci. 49:1560-1568.

Walker, J.W., R.K. Heitschmidt, E.A. deMoreaes, M.M. Kothmann, and S.L. Dowhower. 1989. Quality and botanical composition of cattle diets under rotational and continuous grazing treatments. J. Range Manage. 42:239-242.

Walton, P.D., R. Martinez, and A.W. Bailey. 1981. A comparison of continuous and rotational grazing. J. Range Manage. 34:19-21.

Webb, H.E. 1985. Forage production, disappearance and cow diets on short duration and seasonlong grazing treatments in south-central North Dakota. M.S. Thesis. North Dakota State Univ., Fargo, N.D.

Williams, C.H., D.J. David, and O. Iismaa. 1962. The determination of chromic oxide in faeces samples by atomic absorption spectrophotometry. J. Agr. Sci. (Camb.) 59:381-385. 